\title{
Black Carbon and Heavy Metal Contamination of Soil
}

\author{
Khageshwar Singh Patel ${ }^{1 *}$, Reetu Sharma ${ }^{1}$, Nohar Singh Dahariya ${ }^{1}$, \\ Raj Kishore Patel ${ }^{2}$, Borislav Blazhev ${ }^{3}$, Laurent Matini ${ }^{4}$
}

\author{
${ }^{1}$ School of Studies in Chemistry, Pt. Ravishankar Shukla University, Raipur, India \\ ${ }^{2}$ Department of Chemistry, National Institute of Technology, Rourkela, India \\ ${ }^{3}$ Central Laboratory for Chemical Testing and Control, 1330 Sofia, Bulgaria \\ ${ }^{4}$ Department of Exact Sciences, Marien Ngouabi University, Brazzaville, Congo
}

Received: 19 May 2015

Accepted: 18 December 2015

\begin{abstract}
Black carbon $(\mathrm{BC})$ and heavy metals $\left(\mathrm{HM}_{\mathrm{s}}\right)$ are of great interest to researchers due to their hazardous impact on the environment. Coal is a dirty fuel and its huge exploitation (mining and combustion) causes serious pollution of the environment. In this work, the contamination by $\mathrm{BC}$ and $\mathrm{HM}_{\mathrm{s}}$ of the soil of the coal basin in Korba, India, was evaluated. Higher concentrations of BC and Fe were detected in the soil samples, ranging $(\mathrm{n}=9)$ from 4.5-7.3 and 4.1-9.3\% with mean value of 5.5 and $6.6 \%$, respectively. Concentrations of As, $\mathrm{Cr}, \mathrm{Mn}, \mathrm{Cu}, \mathrm{Zn}, \mathrm{Cd}, \mathrm{Pb}$, and $\mathrm{Hg}$ in the surface soil ( $\mathrm{n}=9$ ) ranged from 91-116, 88-109, 2,423-5,063, $140-479,128-377,1.25-2.73,858-4,973$, and $0.88-2.37 \mathrm{mg} \mathrm{kg}^{-1}$ with values of $101 \pm 5,98 \pm 5,3409 \pm 721$, $229 \pm 72,227 \pm 48,1.84 \pm 0.35,2068 \pm 882$, and $1.45 \pm 0.33 \mathrm{mg} \mathrm{kg}^{-1}$, respectively. Among $\mathrm{HM}_{\mathrm{s}}, \mathrm{Pb}$ is extremely enriched in the soil. The main sources of HMs in the soil apportioned are coal burning and mining.
\end{abstract}

Keywords: black carbons, heavy metals, soil, India

\section{Introduction}

Coal is a natural combustible material that contains elemental carbon, sulfur, trace metals, hydrocarbons, etc. [1-3]. Complex environmental issues, i.e., acid drainage, storage of solid waste, air pollution, deposition of toxic compounds, halting of acid rain, health hazards, etc., have appeared due to huge exploitation (mining and burning) of coal [4-14]. The ash contributes $\geq 30 \%$ of the lignite coal and its main constituents are carbon, alumina, iron, silica, heavy metals, etc. [15-17]. The coal ash exits in the form of fine particles and is linked to various health problems,

*e-mail: patelkhageshwarsingh $@$ gmail.com i.e., organ disease, cancer, respiratory illness, neurological damage, and developmental problems, and it even kills plants and animals [18].

Black carbon (BC), a major constituent of air and fly ash particulates, contributes to global warming through absorption of solar irradiance [19-20]. BC is a good adsorbent for toxic chemicals, i.e., heavy metals, polycyclic aromatic hydrocarbons (PAHs), dioxins, furans (PCDD/Fs), PCBs, and PBDEs due to its high surface-tovolume ratio and a strong affinity [21-24]. The $\mathrm{BC}$ in soil changes the cyclic process of organic matter and increases cation exchange capacity of soil [25]. The $\mathrm{HM}_{\mathrm{s}}$ in soil affects the quality of food, groundwater, micro-organism activity, and plant growth [26-27]. The rain, runoff, and groundwater were suspected to be contaminated with $\mathrm{HM}_{\mathrm{s}}$ 
in the Korba Basin due to the burning of several million tons of coal [28-29]. Keeping all the above facts in mind, the present work was undertaken to evaluate the status of soil in terms of the contamination and sources of $\mathrm{BC}$ and $\mathrm{HM}_{\mathrm{s}}$ in the surface soil of the Korba Basin.

\section{Material and Methods}

\section{Study Area}

The richest coal deposits in India are found in the Korba Basin $\left(22^{\circ} 35^{\prime} \mathrm{N} ; 82^{\circ} 68^{\prime} \mathrm{E}\right)$. Several open and underground coal mines are in operation with annual production of $\approx 3$ BT coal annually since year 1960 . A huge amount of lignite coal (>10000 MT annually) is consumed by various thermal power plants that emit several million tons of fly ash in the environment. The population of the Korba area inclusive of suburbs is $\approx 0.5$ million. The environment of Korba city is polluted due to the huge exploitation of coal [28-29].

\section{Sample Collection}

The soil samples were collected from nine locations of the Korba Basin situated over $\mathrm{a} \approx 1,000 \mathrm{~km}^{2}$ area

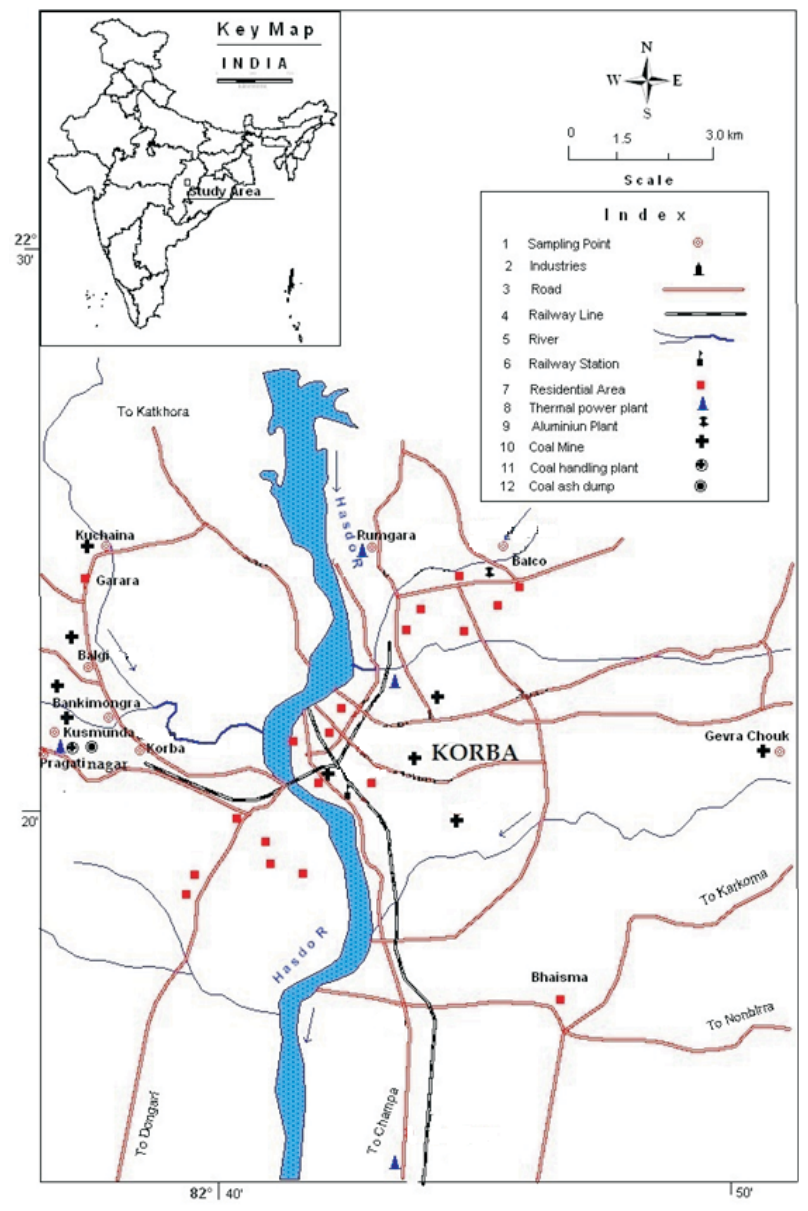

Fig. 1. Representation of sampling locations in the Korba area, India.
(Fig. 1). A 5-cm surface layer of the core was stripped off and the rest of the sample was taken. Approximately $1 \mathrm{~kg}$ of surface soil samples $(0-15 \mathrm{~cm})$ were collected at a radius of $\approx 5 \mathrm{~cm}$ in a clean polyethylene container during January, 2011, as prescribed in the literature [30]. For depth profile studies, the samples were collected in an airtight container at depths of 0-15, 15-30, and $30-45 \mathrm{~cm}$ as per the standard procedure. The samples were transported to a laboratory for analysis.

\section{Sample Preparation}

Soil samples were air dried, ground with a mortar and pestle, and then sieved through a $1-\mathrm{mm}$ sieve to achieve a homogenous sample.

The P/T MARS CEM (Varian Company) microwave digester was used for the digestion of soil samples at $200^{\circ} \mathrm{C}$ with a hold time of $15 \mathrm{~min}$. The soil sample $(0.25 \mathrm{~g})$ was digested with aqua regia $\left(2 \mathrm{~mL}\right.$ of $\mathrm{HNO}_{3}$, $65 \%, \mathrm{v} / \mathrm{v}+6 \mathrm{~mL}$ of $\mathrm{HCl}, 37 \%, \mathrm{v} / \mathrm{v})$ using the EN 13346-2001 method [31].

\section{pH Determination}

Soil particles of $\leq 1 \mathrm{~mm}$ were used to determine $\mathrm{pH}$ values using a suspension of 1:2 (m/v) soil-to-deionized water in a $100-\mathrm{mL}$ conical flask. The suspension was allowed to stand overnight (12 hr) and measured by a Hanna pH meter type-HI991300.

\section{Metal Analysis}

The ICP OES (Varian Liberty-II Radial) was used for analysis of metals, i.e., $\mathrm{Fe}, \mathrm{Cr}, \mathrm{Mn}, \mathrm{Cu}$, and $\mathrm{Zn}$ due to good detection limits $\left(\approx 2.5 \mathrm{mg} \mathrm{kg}^{-1}\right)$. A SpectrAA 220 Zeeman GFAAS (detection limits of $<0.3 \mu \mathrm{g} \mathrm{kg} \mathrm{kg}^{-1}$ ) was employed for analysis of $\mathrm{As}, \mathrm{Cd}$, and $\mathrm{Pb}$. The CVAAS SpectrAA 55B (detection $<0.02 \mu \mathrm{g} \mathrm{kg}^{-1}$ ) was used for the monitoring of Hg. The standard NCS DC 73382 CRM soil sample was employed quality control of the analysis. All measurements were carried out in triplicate and their mean values were reported.

\section{Carbon Analysis}

A CHNSO-IRMS Analyzer by SV Instruments Analytica Pvt. Ltd was used for analysis of total carbon (TC). TC, i.e., black carbon or elemental carbon (BC or EC), organic carbon (OC), and carbonate carbon or inorganic carbon (CC or IC) were analyzed in the soil samples. The soil sample (15 mg) was oxidized with $\mathrm{O}_{2}$ at $1,020^{\circ} \mathrm{C}$ with constant flow of helium. The resulting $\mathrm{CO}_{2}$ gas was detected by a thermal conductivity detector. The $\mathrm{H}_{3} \mathrm{PO}_{4}$-treated soil sample (10 drops) was oxidized with $\mathrm{O}_{2}$ at $1,020^{\circ} \mathrm{C}$ in a similar way to determine $\mathrm{BC}$ and $\mathrm{OC}$ contents. The $\mathrm{OC}$ content was analyzed by titration method using $\mathrm{K}_{2} \mathrm{Cr}_{2} \mathrm{O}_{7}$ as oxidant, and the excess of $\mathrm{K}_{2} \mathrm{Cr}_{2} \mathrm{O}_{7}$ was determined by back titration with the $\mathrm{FeSO}_{4} \cdot 7 \mathrm{H}_{2} \mathrm{O}$ solution [32]. The CC content in the soil was evaluated by 
Table 1. Physico-chemical characteristics of surface soil.

\begin{tabular}{|c|c|c|c|c|c|c|}
\hline S. No. & Location & Color & $\mathrm{pH}$ & $\mathrm{BC}(\%)$ & OC (\%) & CC (\%) \\
\hline 1 & Rumgara & $\mathrm{Br}$ & 6.94 & 6.3 & 0.65 & 0.33 \\
\hline 2 & Pragati Nagar & $\mathrm{Gr}$ & 6.94 & 4.5 & 0.34 & 0.19 \\
\hline 3 & Gevera Chowk & $\mathrm{Bk}$ & 6.65 & 4.8 & 0.35 & 0.22 \\
\hline 4 & Kusmunada colony & $\mathrm{Br}$ & 6.68 & 4.6 & 0.34 & 0.20 \\
\hline 5 & Korba & $\mathrm{Gr}$ & 5.37 & 5.4 & 0.44 & 0.22 \\
\hline 6 & Banki mongra & $\mathrm{Br}$ & 6.47 & 5.6 & 0.54 & 0.23 \\
\hline 7 & Balgi & $\mathrm{Bk}$ & 7.03 & 5.5 & 0.44 & 0.24 \\
\hline 8 & Kuchaina & $\mathrm{Br}$ & 6.75 & 7.3 & 0.75 & 0.36 \\
\hline 9 & Balco & $\mathrm{Bk}$ & 5.70 & 5.7 & 0.64 & 0.32 \\
\hline
\end{tabular}

$\mathrm{Br}=$ Brown, $\mathrm{Bk}=$ Blackish, $\mathrm{Gr}=$ Gray, $\mathrm{SECL}=$ South eastern coal Ltd.

subtracting the $\mathrm{BC}$ and $\mathrm{OC}$ content to the $\mathrm{TC}$ by using the following equation:

$$
\mathrm{CC}=\mathrm{TC}-(\mathrm{BC}+\mathrm{OC})
$$

Pollution Indices

The pollution indices, i.e., enrichment factor (EF), contamination factor (CF), geo-accumulation index (GAI), pollution load index (PLI), and ecological risk index (ERI), were used for geochemistry assessment of the $\mathrm{HM}_{\mathrm{s}}$ [33]. Among them, the EF value was used to assess pollution of $\mathrm{HM}_{\mathrm{s}}$ in soil with respect to crustal contributions [34]:

$$
\mathrm{EF}=\left(\left[\mathrm{C}_{\mathrm{m}}\right] /\left[\mathrm{C}_{\mathrm{Al}}\right]\right)_{\text {soil }} /\left(\left[\mathrm{C}_{\mathrm{m}}\right] /\left[\mathrm{C}_{\mathrm{Al}}\right]\right)_{\text {crust }}
$$

...where, $\mathrm{C}_{\mathrm{m}}$ and $\mathrm{C}_{\mathrm{Al}}$ denote the concentrations of the metal and aluminum in the soil and crust. Five contamination categories were recognized on the basis of the enrichment factor: $\mathrm{EF}<2$, depletion to mineral enrichment; $2 \geq \mathrm{EF}<5$, moderate enrichment; $5 \geq \mathrm{EF}<20$, significant enrichment; $20 \geq E F<40$, very high enrichment; and $\mathrm{EF}>40$, extremely high enrichment [35].

A contamination factor $(\mathrm{CF})$ was used to describe the contamination of a given toxic substance in the geomedia [36]:

$$
\mathrm{CF}=\left(\left[\mathrm{C}_{\mathrm{m}}\right]_{\text {soil }} /\left[\mathrm{C}_{\mathrm{m}}\right]_{\text {crust }}\right)
$$

The following terminologies were used to mention the contamination factor: $\mathrm{CF}<1$, low contamination factor; $1 \geq \mathrm{CF}<3$, moderate contamination factors; $3 \geq \mathrm{CF}<6$, considerable contamination factors; and $\mathrm{CF} \geq 6$, very high contamination factor. A root of the product of $\mathrm{CF}$ can be defined as pollution load index (PLI):

$$
\mathrm{PLI}=\left(\mathrm{CF}_{1} \times \mathrm{CF}_{2} \times \mathrm{CF}_{3} \times \mathrm{CF}_{4} \times \ldots \mathrm{CF}_{\mathrm{n}}\right)^{1 / \mathrm{n}}
$$

The pollution load index (PLI) provides a simple and comparative means for assessing the level of heavy metal pollution. An index of the geo-accumulation index (GI) is used to determine metal contamination in the geomedia by comparing current concentrations with pre-industrial levels [37-38]:

Table 2. Heavy metals contents in surface soil $\left(\mathrm{mg} \mathrm{kg}^{-1}\right)$.

\begin{tabular}{|c|c|c|c|c|c|c|c|c|c|}
\hline S. No. & $\mathrm{Fe}(\%)$ & $\mathrm{As}$ & $\mathrm{Cr}$ & $\mathrm{Mn}$ & $\mathrm{Cu}$ & $\mathrm{Zn}$ & $\mathrm{Cd}$ & $\mathrm{Pb}$ & $\mathrm{Hg}$ \\
\hline 1 & 7.6 & 110 & 107 & 4969 & 336 & 249 & 2.41 & 1670 & 2.05 \\
\hline 2 & 4.1 & 102 & 91 & 2656 & 140 & 128 & 1.25 & 858 & 0.88 \\
\hline 3 & 4.9 & 96 & 96 & 2934 & 189 & 183 & 1.32 & 1250 & 1.12 \\
\hline 4 & 6.6 & 95 & 97 & 2466 & 147 & 177 & 1.3 & 1132 & 1.02 \\
\hline 5 & 5.6 & 96 & 88 & 2423 & 169 & 207 & 1.56 & 1410 & 1.31 \\
\hline 6 & 6.8 & 91 & 94 & 2854 & 197 & 286 & 2.08 & 1798 & 1.4 \\
\hline 7 & 7.4 & 97 & 98 & 2801 & 172 & 254 & 1.77 & 1892 & 1.19 \\
\hline 8 & 9.3 & 116 & 109 & 5063 & 479 & 377 & 2.73 & 4973 & 2.37 \\
\hline 9 & 7.4 & 104 & 105 & 4518 & 230 & 183 & 2.11 & 3628 & 1.74 \\
\hline
\end{tabular}


Table 3. Statistics of metal concentrations in surface soil $\left(\mathrm{mg} \mathrm{kg}^{-1}\right)$.

\begin{tabular}{|c|c|c|c|c|c|c|c|c|c|}
\hline Parameter & $\mathrm{Fe}(\%)$ & $\mathrm{As}$ & $\mathrm{Cr}$ & $\mathrm{Mn}$ & $\mathrm{Cu}$ & $\mathrm{Zn}$ & $\mathrm{Cd}$ & $\mathrm{Pb}$ & $\mathrm{Hg}$ \\
\hline Min & 1.8 & 91 & 34 & 314 & 140 & 126 & 1.1 & 858 & 0.10 \\
\hline $\mathrm{Max}$ & 9.3 & 116 & 109 & 5063 & 479 & 510 & 2.73 & 4973 & 2.37 \\
\hline $\mathrm{AM}$ & 5.3 & 100 & 81 & 2365 & 200 & 219 & 1.62 & 1776 & 0.92 \\
\hline $\mathrm{GM}$ & 4.8 & 99 & 77 & 1762 & 187 & 201 & 1.56 & 564 & 0.53 \\
\hline $\mathrm{MV}$ & 4.9 & 98 & 91 & 2466 & 165 & 183 & 1.39 & 858 & 1.02 \\
\hline $\mathrm{STD}, \pm$ & 2.2 & 7 & 24 & 1593 & 92 & 107 & 0.5 & 1350 & 0.80 \\
\hline $\mathrm{CL}, \pm$ & 1.1 & 3 & 12 & 779 & 61 & 61 & 0.3 & 882 & 0.40 \\
\hline $\mathrm{Skew}$ & 0.16 & 0.93 & -0.63 & 0.40 & 2.52 & 1.74 & 1.10 & 1.62 & 0.39 \\
\hline $\mathrm{Ku}$ & -0.91 & 0.62 & -0.95 & -0.85 & 6.37 & 3.14 & 0.28 & 1.9 & -0.99 \\
\hline
\end{tabular}

$\mathrm{AM}=$ Arithmatic mean, $\mathrm{GM}=$ Geometric mean, $\mathrm{MV}=$ Median value, $\mathrm{CL}=$ Confidence limit, $\mathrm{Skew}=$ Skewness, $\mathrm{Ku}=\mathrm{Kurtosis}$

$$
\mathrm{GI}=\log _{2}\left(\left[\mathrm{C}_{\mathrm{m}}\right]_{\text {soil }} /\left[1.5 \mathrm{C}_{\mathrm{m}}\right]_{\text {crust }}\right)
$$

The geo-accumulation index (GAI) was distinguished into seven classes by Müller: $\mathrm{GI} \leq 0$, class 0 , unpolluted; $0>\mathrm{GI} \leq 1$, class 1 , from unpolluted to moderately polluted; $1>\mathrm{GI} \leq 2$, class 2 , moderately polluted; $2>\mathrm{GI} \leq 3$, class 3 , from moderately to strongly polluted; $3>\mathrm{GI} \leq 4$, class 4 , strongly polluted; $4>\mathrm{GI} \leq 5$, class 5 , from strongly to extremely polluted; and GI $>5$, class 6 , extremely polluted.

a)

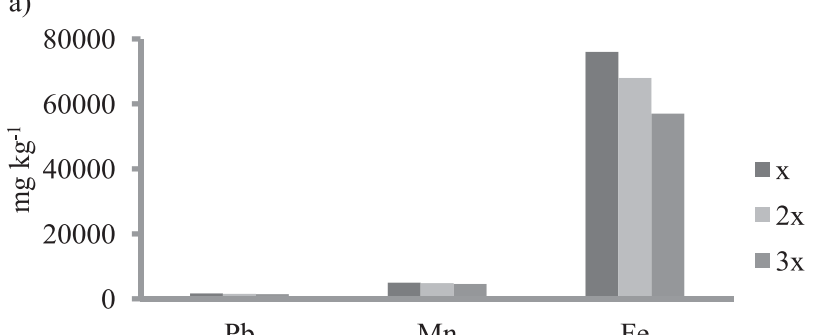

b)

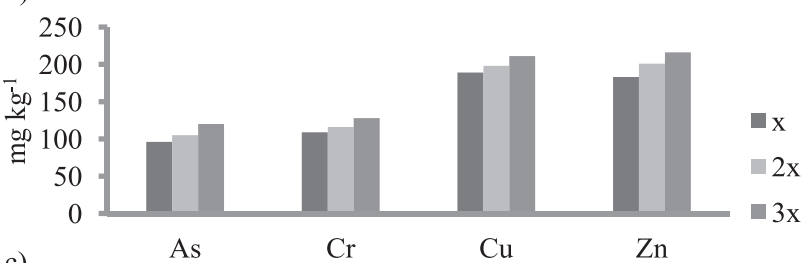

c)

As

$\mathrm{Cr}$

$\mathrm{Cu}$

$\mathrm{Zn}$

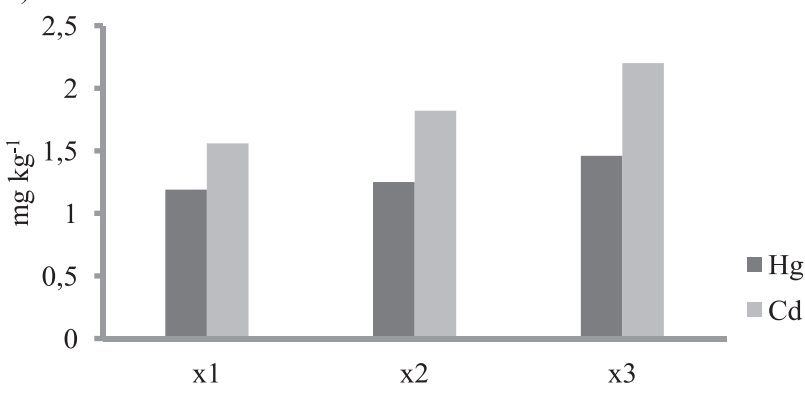

Depth profile, $\mathrm{cm}$

Fig. 2. Vertical distribution of metals, a) x1 $(0-15 \mathrm{~cm}), \mathrm{b}) \times 2(15-$ $30 \mathrm{~cm})$, and c) x3 $(30-45 \mathrm{~cm})$.
Ecological risk index (ERI) was used to measure both risk factor and metal concentrations in soil. The ERI value was determined through the following equation:

$$
\mathrm{ERI}=\operatorname{Tr} \mathrm{x} C F
$$

...where, $\operatorname{Tr}$ is the potential ecological risk factor/index. The toxic response value for metals reported are $\mathrm{As}=10$, $\mathrm{Cr}=2, \mathrm{Cd}=30, \mathrm{Cu}=5, \mathrm{~Pb}=5, \mathrm{Hg}=40$, and $\mathrm{Zn}=1$ [39].

\section{Statistical Analysis}

The confidence limit of the data was reported at 95\% probability. Factor analysis was used to assess BC and $\mathrm{HM}_{\mathrm{s}}$ contamination in the soil [40-41].

\section{Results and Discussion}

\section{$\mathrm{pH}$ of Soil Extract}

The physico-chemical characteristics of the soils are summarized in Table 1. The soil was colored, ranging from brown $(\mathrm{Br})$ to blackish $(\mathrm{Bk})$. The $\mathrm{pH}$ value of the soil extracts was ranged from 5.4-7.0 with mean value of $6.4 \pm 0.4$. The soil of the studied area was found to be slightly acidic due to deposition of acids by the burning coal [42].

\section{Carbon Concentration}

Three types of carbons: BC, OC, and CC were analyzed in the soil. Their concentrations ranged $(n=9)$ from $4.5-7.3,0.34-0.75$, and $0.19-0.36 \%$, with mean values of $5.5 \pm 0.6,0.50 \pm 0.13$, and $0.26 \pm 0.04 \%$, respectively. Good correlations ( $\mathrm{r}=0.91-0.95)$ of the $\mathrm{BC}$ with the $\mathrm{OC}$ and $\mathrm{CC}$ were observed, may be due to their similarity in origin. The carbon concentration in the soil of the study area was found to be higher than the soils of other regions of the world [43-49]. 
Table 4. Results of Factor analysis of heavy metals in the soil.

\begin{tabular}{|c|c|}
\hline Variable & Factor 1 \\
\hline $\mathrm{BC}$ & -0.98 \\
\hline $\mathrm{Fe}$ & -0.98 \\
\hline $\mathrm{As}$ & -0.93 \\
\hline $\mathrm{Hg}$ & -0.89 \\
\hline $\mathrm{Pb}$ & -0.76 \\
\hline $\mathrm{Zn}$ & -0.95 \\
\hline $\mathrm{Cd}$ & -0.75 \\
\hline $\mathrm{Cu}$ & -0.85 \\
\hline $\mathrm{Mn}$ & -0.84 \\
\hline $\mathrm{Cr}$ & -0.90 \\
\hline Eigen value & 7.85 \\
\hline$\%$ Variance & 78.50 \\
\hline$\%$ Cumulative Variance & 78.50 \\
\hline
\end{tabular}

Loading value $>0.70$ (in absolute value), significant at $\mathrm{p}<0.05$.

\section{Heavy Metal Concentrations}

The concentrations of nine metals in the surface soil of Korba Basin is presented in Table 2. Among them, the highest concentration of $\mathrm{Fe}$ was observed, ranging from $4.1-9.3 \%$ with mean value of $6.6 \%$. The concentration of other $\mathrm{HM}_{\mathrm{s}}$, i.e., As, $\mathrm{Cr}, \mathrm{Mn}, \mathrm{Cu}, \mathrm{Zn}, \mathrm{Cd}, \mathrm{Pb}$, and $\mathrm{Hg}$ in the surface soil $(\mathrm{n}=9)$ ranged from 91-116, 88-109, 2,423-5,063, 140-479, 128-377, 1.25-2.73, 858-4,973, and $0.88-2.73 \mathrm{mg} \mathrm{kg}^{-1}$ with mean value of $101 \pm 5,98 \pm 5$, $3,409 \pm 721,229 \pm 72,227 \pm 78,1.84 \pm 0.36,2,068 \pm 882$, and $1.45 \pm 0.33 \mathrm{mg} \mathrm{kg}^{-1}$, respectively. The geometric mean (GM) values for $\mathrm{As}, \mathrm{Cr}, \mathrm{Mn}, \mathrm{Cu}, \mathrm{Zn}, \mathrm{Cd}, \mathrm{Pb}$, and $\mathrm{Hg}$ were $101,98,3,266,211,217,1.77,1,776$, and 1.38, and were found to be comparable with the arithmetic mean value. The skewness and kurtosis values ranged from -0.11.8 and $-0.02-2.9$, respectively (Table 3 ). The highest concentration of the $\mathrm{HM}_{\mathrm{s}}$ (i.e., $\mathrm{Fe}, \mathrm{Mn}, \mathrm{Zn}, \mathrm{Cd}, \mathrm{Pb}$, and As) was seen at the location of Kuchaina and may be due to running the thermal power plant at a distance of $\approx 5 \mathrm{~km}$ away in the wind direction (Table 2). The $\mathrm{HM}_{\mathrm{s}}$ content in the soil of the basin was seem to be higher than the contents reported in the soil of other regions of the country and the world [50-55].

\section{Depth Profile Studies}

The vertical distribution of the metals in the soil is presented in Fig. 2. The distribution ratio of metals, i.e., Fe, $\mathrm{Mn}$, and $\mathrm{Pb}$, was decreased vertically when the depth profile was increased from 0-45 cm due to chemical reactions with organic matters. These metals remained deposited in the topsoil layers. Among them, the highest concentration of Fe was observed in the topsoils due to the lowest distribution ratio $(\mathrm{d}=0.8)$. The vertical transport of other $\mathrm{HM}_{\mathrm{s}}$, i.e., As, $\mathrm{Cr}, \mathrm{Cu}, \mathrm{Ni}, \mathrm{Zn}, \mathrm{Cd}$, and $\mathrm{Hg}$, was increased when the depth profile was increased $0-45 \mathrm{~cm}$, perhaps due to their decreased binding with organic matter. Among them, the highest distribution ratio $(\mathrm{d}=1.4)$ was observed for $\mathrm{Cd}$, possibly due to the higher solubility of its compounds.

\section{Pollution Indices}

The background concentrations of $\mathrm{Al}, \mathrm{Fe}, \mathrm{As}, \mathrm{Cr}, \mathrm{Mn}$, $\mathrm{Cu}, \mathrm{Zn}, \mathrm{Cd}, \mathrm{Pb}$, and $\mathrm{Hg}$ in the earth's crust were recorded as $81,500,39,200,4.8,92,774,28,67,0.09,17$, and 0.05 $\mathrm{mg} \mathrm{kg}^{-1}$, respectively [56]. The $\mathrm{HM}_{\mathrm{s}}$ incursion in soil of the study area was described by four factors: EF, PLI, GAI, and ERI.

The mean EF values for $\mathrm{Pb}, \mathrm{Hg}, \mathrm{As}, \mathrm{Cd}, \mathrm{Cu}, \mathrm{Mn}, \mathrm{Zn}$, $\mathrm{Fe}$, and $\mathrm{Cr}$ were found to be 137, 31, 22, 22, 8.5, 4.7, 3.6, 2.0, and 1.2, respectively. The metals: $\mathrm{Pb}$; $\mathrm{Hg}$, As, and $\mathrm{Cd}$; $\mathrm{Cu}$; and $\mathrm{Mn}, \mathrm{Zn}$, and Fe were extremely, highly, significantly, and moderately enriched in the soil me-

Table 5. Correlation matrix of the variables for soils.

\begin{tabular}{|c|c|c|c|c|c|c|c|c|c|c|}
\hline & $\mathrm{BC}$ & $\mathrm{Fe}$ & $\mathrm{As}$ & $\mathrm{Hg}$ & $\mathrm{Pb}$ & $\mathrm{Zn}$ & $\mathrm{Cd}$ & $\mathrm{Cu}$ & $\mathrm{Mn}$ & $\mathrm{Cr}$ \\
\hline $\mathrm{BC}$ & 1.00 & & & & & & & & & \\
\hline $\mathrm{Fe}$ & 0.87 & 1.00 & & & & & & & & \\
\hline $\mathrm{As}$ & 0.74 & 0.57 & 1.00 & & & & & & & \\
\hline $\mathrm{Hg}$ & 0.75 & 0.82 & 0.79 & 1.00 & & & & & & \\
\hline $\mathrm{Pb}$ & 0.82 & 0.72 & 0.88 & 0.93 & 1.00 & & & & & \\
\hline $\mathrm{Zn}$ & 0.93 & 0.78 & 0.87 & 0.82 & 0.88 & 1.00 & & & & \\
\hline $\mathrm{Cd}$ & 0.88 & 0.83 & 0.45 & 0.54 & 0.53 & 0.80 & 1.00 & & & \\
\hline $\mathrm{Cu}$ & 0.96 & 0.88 & 0.70 & 0.79 & 0.87 & 0.88 & 0.83 & 1.00 & & \\
\hline $\mathrm{Mn}$ & 0.83 & 0.80 & 0.69 & 0.74 & 0.76 & 0.80 & 0.69 & 0.80 & 1.00 & \\
\hline $\mathrm{Cr}$ & 0.96 & 0.83 & 0.81 & 0.84 & 0.93 & 0.95 & 0.76 & 0.96 & 0.82 & 1.00 \\
\hline
\end{tabular}


dia, respectively. The EF values for metals in the studied area were observed in the following decreasing trend: $\mathrm{Pb}>\mathrm{Hg}>\mathrm{As} \approx \mathrm{Cd}>\mathrm{Cu}>\mathrm{Mn}>\mathrm{Zn}>\mathrm{Fe}>\mathrm{Cr}$.

The mean $\mathrm{CF}$ values for $\mathrm{Pb}, \mathrm{Hg}, \mathrm{As}, \mathrm{Cd}, \mathrm{Cu}, \mathrm{Mn}, \mathrm{Zn}$, $\mathrm{Fe}$, and $\mathrm{Cr}$ were 122, 29, 21, 20, 8.2, 4.4, 3.4, 1.7, and 1.1 , respectively. The similar decreasing trend of the $\mathrm{HM}_{\mathrm{s}}$ contamination of the soil was marked. The PLI value for $\mathrm{Pb}, \mathrm{Hg}, \mathrm{As}, \mathrm{Cd}, \mathrm{Cu}, \mathrm{Mn}, \mathrm{Zn}, \mathrm{Fe}$, and $\mathrm{Cr}$ was 104, 28, 21, $20,7.5,4.2,3.2$, 1.6, and 1.1, respectively. The PLI values confirmed that soil was polluted strongly with meals, i.e., $\mathrm{Pb}, \mathrm{Hg}, \mathrm{As}$, and $\mathrm{Cd}$.

Similarly, the mean GAI values for $\mathrm{Pb}, \mathrm{Hg}, \mathrm{As}, \mathrm{Cd}, \mathrm{Cu}$, $\mathrm{Mn}, \mathrm{Zn}, \mathrm{Fe}$, and $\mathrm{Cr}$ were 6.4, 4.3, 3.8, 3.8, 2.5, 1.6, 1.2, 0.2 , and -0.49 , respectively, and their pollutions are categorised into the following classes. The soils are severely to extremely, strongly, moderately, and unpolluted with $\mathrm{Pb}$; As and $\mathrm{Cd}$; $\mathrm{Cu}, \mathrm{Mn}$, and $\mathrm{Zn}$; and $\mathrm{Fe}$ and $\mathrm{Cr}$, respectively. The ERI values for $\mathrm{Hg}, \mathrm{Pb}, \mathrm{Cd}, \mathrm{As}, \mathrm{Cu}, \mathrm{Zn}$, and $\mathrm{Cr}$ for the soil of the studied area were found to be 1,160, 610, $600,210,41,3.4$, and 2.0, respectively. Very high risk exposures $(\mathrm{ERI} \geq 320)$ of the three metals $\mathrm{Hg}, \mathrm{Pb}$, and $\mathrm{Cd}$ in the environment were expected, whereas, high (ERI < $320)$ and moderate $(E R I>40)$ risk exposures for As and $\mathrm{Cu}$ were assumed.

\section{Sources}

The results of the factor analysis (FA) are shown in Table 4. In this work, only one factor of the FA, including $78.5 \%$ of the total variance, was extracted. All the loadings were significant in the absolute value and well associated with Factor 1. This factor was negatively correlated with all the metals. The higher association of the $\mathrm{HM}_{\mathrm{s}}$ with the $\mathrm{BC}$ was marked (Table 5). This identified the activities related to the coal burning and mining as the source of the $\mathrm{HM}_{\mathrm{s}}$ in the soil. The $\mathrm{HM}_{\mathrm{s}}$ in the soil were also strongly correlated with the Fe content, but to a smaller extent than with the Mn.

\section{Conclusions}

The high BC content in Korba Basin surface soil tends to accumulate the $\mathrm{HM}_{\mathrm{s}}$ at dangerous levels. The soil is highly polluted with very toxic metals, i.e., $\mathrm{Pb}, \mathrm{Hg}$, As, and $\mathrm{Cd}$ due to continuous coal exploitation (i.e., burning and mining) at huge levels. Among toxic metals, the highest mobility for $\mathrm{Cd}$ through soil media was observed. The multi-pollution index analysis approaches showed that toxic metals, i.e., $\mathrm{Pb}, \mathrm{Hg}$, As, and $\mathrm{Cd}$ can cause serious environmental problems in the Korba Basin ecosystem. The alarming situation of these toxic metals in the studied area should be regularly monitored for health-related problems in the inhabitants.

\section{References}

1. COOPER B.S., MURCHISON D.G. "Organic geochemistry of coal.” In Organic Geochemistry, edited by Eglinton G., and M.T.J. Murphy, Springer-Verlag, New York, 1969.

2. SAIKIA B.K., GOSWAMEE R.L., BARUAH B.P., BARUAH R.K. Occurrence of some hazardous metals in Indian coals. Coke and Chemistry 52 (2), 54, 2009.

3. CHOU C.L. Sulfur in coals: A review of geochemistry and origins. International Journal of Coal Geology 100 (10), 1, 2012.

4. CHANDRAWANSHI C.K., PATEL V.K., PATEL K.S. Acid rain in Korba city of India. Indian Journal of Environmental Protection 17, 656, 1997.

5. PATEL K.S., SHUKLA A., TRIPATHI A.N., HOFFMANN P. Heavy metal concentrations of precipitation in east Madhya Pradesh of India. Water Air Soil Pollution 130 (14), 463, 2001

6. MANDAL A., SENGUPTA D. An assessment of soil contamination due to heavy metals around a coal-fired thermal power plant in India. Environmental Geology 51 (3), 409, 2006.

7. AGRAWAL P., MITTAL A., PRAKASH R., KUMAR M., SINGH T.B., TRIPATHI S.K. Assessment of contamination of soil due to heavy metals around coal fired thermal power plants at Singrauli region of India. Bulletin of Environmental Contamination and Toxicology 85 (2), 219, 2010.

8. BHUIYAN M.A., PARVEZ L., ISLAM M.A., DAMPARE S.B., SUZUKI S. Heavy metal pollution of coal mineaffected agricultural soils in the northern part of Bangladesh. Journal of Hazardous Materials 173 (1-3), 384, 2010.

9. SENGUPTA S., CHATTERJEE T., GHOSH P.B., SAHA T. Heavy metal accumulation in agricultural soils around a coal fired thermal power plant (Farakka) in India. Journal of Environmental Science and Engineering 52 (4), 299, 2010.

10. SINGH R., SINGH D.P., KUMAR N., BHARGAVA S.K., BARMAN S.C. Accumulation and translocation of heavy metals in soil and plants from fly ash contaminated area. Journal of Environmental Biology 31 (4), 421, 2010.

11. SHEORAN V., SHEORAN A.S., THOLIA N.K. Acid mine drainage: An overview of Indian mining industry. International Journal of Earth Science and Engineering 4 (6), 1075, 2011.

12. GUTTIKUNDA S.K., JAWAHAR P. Atmospheric emissions and pollution from the coal-fired thermal power plants in India. Atmospheric Environment 92, 449, 2014.

13. DAS S.K., CHAKRAPANI G.J. Assessment of trace metal toxicity in soils of Raniganj coalfield, India. Environmental Monitoring and Assessment 177 (1-4), 63, 2011.

14. BURT E., ORRIS P., BUCHANAN S. Scientific evidence of health effects from coal use in energy generation, UIC, School of Public Health, Chicago, USA, 2013.

15. SARKAR A., RANO R., UDAYBHANU G., BASU A.K. A comprehensive characterization of fly ash from a thermal power plant in Eastern India. Fuel Processing Technology 87 (3), 259, 2006.

16. SUSHIL S., BATRA V.S. Analysis of fly ash heavy metal content and disposal in three thermal power plants in India. Fuel 85 (17-18), 2676, 2006.

17. BHANARKAR A.D., GAVANE A.G., TAJNE D.S., TAMHANE S.M., NEMA P. Composition and size distribution of particulates emissions from a coal-fired power plant in India. Fuel 87 (10-11), 2095, 2008.

18. BORM P.J.A. Toxicity and occupational health hazards of coal fly ash (CFA): A review of data and comparison to coal mine dust. Annals of Occupational Hygiene 41 (6), 659, 1977.

19. DONALDSON K., TRAN L., JIMENEZ L.A., DUFFIN R., NEWBY D.E., MILLS N., MACNEE W., STONE V. Combustion-derived nanoparticles: A review of their 
toxicology following inhalation exposure. Particle and Fiber Toxicology 2, 1, 2005.

20. RAMANATHAN V., CARMICHAEL G. Global and regional climate changes due to black carbon. Nature Geoscience 1, 221, 2008.

21. CHEN X., XIA X., ZHAO Y., ZHANG P. Heavy metal concentrations in roadside soils and correlation with urban traffic in Beijing, China. Journal of Hazardous Materials 181 (1-3), 640, 2010

22. RAY S., KHILLARE P.S., KIM K.H., BROWN R.J. Distribution, sources, and association of polycyclic aromatic hydrocarbons, black carbon, and total organic carbon in size-segregated soil samples along a background-urban-rural transect. Environmental Engineering Science 29 (11), 1008, 2012.

23. WANG X.S., ZHANG P., ZHOU H.Y., FU J. Association of black carbon with polycyclic aromatic hydrocarbons and heavy metals in urban top soils and environmental implications. International Journal of Environmental Studies 69 (5), 705, 2012.

24. HANY M., BANDOWE B.A.M.,WEI C., CAO J.J., WILCKE W., WANG G.H., NI H.Y., JIN Z.D., AN Z.S., YAN B.Z. Stronger association of polycyclic aromatic hydrocarbons with soot than with char in soils and sediments. Chemosphere 119, 1335, 2014.

25. LIANG B., LEHMANN J., SOLOMON D., KINYANGI J., GROSSMAN J., ONEILL B., SKJEMSTAD J.O., THIES J., LUIZAO F.J., PETERSEN J., NEVES E.G. Black carbon increases cation exchange capacity in soils. Soil Science Society of America Journal 70 (5), 1719, 2006.

26. WANG L.K., CHEN J.P., HUNG Y.T., SHAMMAS N.K. Handbook on heavy metals in the environment, CRC Press, Boca Raton: USA, 2009.

27. SINGH J., KALAMDHAD A.S. Effects of heavy metals on soil, plants, human health and aquatic life. International Journal of Research in Chemistry and Environment 1 (2), 15,2011

28. PATEL K.S., AMBADE B., SHARMA R., DAHARIYA N.S., NICOLÁS J., YUBERO E., MATINI L. Runoff water quality of Korba city, India. Journal of Environmental Protection, Submitted

29. PATEL K.S., DEWANGAN R., WYSOCKA I., JARON I., MATINI L. Ground water pollution in central India. ICWRER Conference Proceeding, Koblenz, Germany. 256, 2013, DOI: 10.5675/ICWRER_2013.

30. TAN K.H. Soil sampling, preparation and analysis. $2^{\text {nd }}$ ed., CRC Press, Boca Raton: FL, 2005.

31. DIN (Deutsches Institut Fur Normung E.V.) Characterization of sludge - Determination of trace elements and phosphorus - Aqua regia extraction methods; English version of DIN EN 13346, 2001.

32. WALKLEY A., BLACK I.A. An examination of the Degtjareff method for determining soil organic matter and a proposed modification of the chromic acid titration method. Soil Science 37, 29, 1934

33. CAEIRO, S., COSTA M.H., RAMOS T.B., FERNANDES F., SILVEIRA N., COIMBRA A., MEDEIROS G., PAINHO M. Assessing heavy metal contamination in Sado estuary sediment: An index analysis approach. Ecological Indicators 5 (2), 151, 2005.

34. SINEX S.A., HELZ G.R. Regional geochemistry of trace elements in Chesapeake Bay sediments. Environmental Geology 3 (6), 315, 1981.

35. SUTHERLAND R.A. Bed sediment-associated trace metals in an urban stream, Oahu, Hawaii. Environmental Geology 39 (6), 611, 2000.
36. TOMLINSON D.L., WILSON J.G., HARRIS C.R., JEFFREY D.W. Problem in the assessment of heavy-metal levels in estuaries and the formation of a pollution index. Helgolander Meeresunters 33 (1-4), 566, 1980.

37. MULLER G. Index of geo-accumulation in sediments of the Rhine River. Geojournal 2 (3), 108, 1969.

38. RUIZ F. Trace metals in estuarine sediments from the south western Spanish coast. Marine Pollution Bulletin 42, 481, 2001.

39. HÅKANSON L. An ecological risk index for aquatic pollution control: A sediment logical approach, Water Research 4 (8), 975, 1980.

40. LIN Y.P., TENG T.P., CHANG T.K. Multivariate analysis of soil heavy metal pollution and landscape pattern in Changhua country in Taiwan. Landscape and Urban Planning 62 (1), 19, 2002.

41. YONGMING H., PEIXUAN D., JUNJI C., POSMENTIER E.S. Multivariate analysis of heavy metal contamination in urban dusts of Xi'an, Central China. Science of the Total Environment 355, 176, 2006.

42. DRISCOLL C.T., LAWRENCE G.B., BULGER A.J., BUTLER T.J., CRONAN C.S., EAGER C., LAMBERT K.F., LIKENS G.E., STODDARD J.L., WEATHERS K.C. Acidic deposition in the Northeastern United States: Sources and inputs, ecosystem effects, and management strategies. BioScience 51 (3), 180, 2001.

43. HAN Y.M., CAO J.J., CHOW J.C., WATSON J.G., AN Z.S., LIU S.X. Elemental carbon in urban soils and road dusts in Xi'an, China and its implication for air pollution. Atmospheric Environmental 43 (15), 2464, 2009.

44. HE Y., ZHANG G.L. Historical record of black carbon in urban soils and its environmental implications. Environmental Pollution 157 (10), 2684, 2009.

45. LIU S., XIA X., ZHAI Y., WANG R., LIU T., ZHANG S. Black carbon (BC) in urban and surrounding rural soils of Beijing, China: Spatial distribution and relationship with polycyclic aromatic hydrocarbons (PAHs). Chemosphere 82 (2), 223, 2011.

46. WANG Q., LIU M., YU Y., DU F., WANG X. Black carbon in soils from different land use areas of Shanghai, China: Level, sources and relationship with polycyclic aromatic hydrocarbons. Applied Geochemistry 47, 36, 2014.

47. WANG W.S. Black carbon in urban topsoils of Xuzhou (China): Environmental implication and magnetic proxy. Environmental Monitoring and Assessment 163 (1), 41, 2010.

48. SANTOS F., FRASER M.P., BIRD J.A. Atmospheric black carbon deposition and characterization of biomass burning tracers in a northern temperate forest. Atmospheric Environment 95, 383, 2014.

49. YANG T., GUILIN H., ZHIFANG X. Atmospheric black carbon deposit in Beijing and Zhangbei, China. Procedia Earth and Planetary Science 10, 383, 2014.

50. YANG T., LIU Q., CHAN L., CAO G. Magnetic investigation of heavy metals contamination in urban top soils around the East Lake, Wuhan, China. Geophysical Journal International 171 (2), 603, 2007

51. WU S., XIA X., CHEN X., ZHOU C. Levels of arsenic and heavy metals in the rural soils of Beijing and their changes over the last two decades. Journal of Hazardous Materials 179 (1-3), 860, 2010.

52. JABOOBI M., ZOUAHRI A., TIJANE M.H., HOUSNI A., MENNANE Z., YACHOU H., BOUKSAIM M. Evaluation of heavy metals pollution in groundwater, soil and some vegetables irrigated with wastewater in the Skhirat region Morocco. Journal of Materials and Environmental Science 5 (3), 961, 2014. 
53. ALI S.M., MALIK R.N. Spatial distribution of metals in top soils of Islamabad City, Pakistan. Environmental Monitoring and Assessment 172 (1-4), 1, 2011.

54. HUSSAIN R., KHATTAK S.A., SHAH M.T., ALI L. Multistatistical approaches for environmental geochemical assessment of pollutants in soils of Gadoon Amazai Industrial Estate, Pakistan. Journal of Soils and Sediments 15, 1119, 2015.
55. MOKHTAR M.M., TAIB R.M., HASSIM M.H. Understanding selected trace elements behavior in a coalfired power plant in Malaysia for assessment of abatement technologies. Journal of the Air and Waste Management Association 64 (8), 867, 2014.

56. RUDNICK R.L., GAO S. "Composition of the continental crust." In The Crust, Treatise on Geochemistry, edited by Holland, H.D., and K.K. Turekian, 3, 1-64. ElsevierPergamum, Oxford, 2003. 